\title{
Pengaruh Implementasi Prinsip-Prinsip Good Corporate Governance dan Manajemen Risiko pada Kinerja Keuangan Koperasi Simpan Pinjam di Kecamatan Buleleng
}

\author{
Kadek Marsa Kusuma Putra ${ }^{1 *}$, Wayan Cipta ${ }^{2}$ iD \\ ${ }^{12}$ Program Studi Manajemen, Universitas Pendidikan Ganesha, Singaraja, Indonesia \\ *kadekmarsakusumaputra615@gmail.com ${ }^{1 *}$
}

\section{Abstrak}

Penelitian ini Penelitian ini bertujuan untuk menguji pengaruh good corporate governance dan manajemen risiko terhadap kinerja keuangan pada koperasi simpan pinjam di Kecamatan Buleleng. Penelitian ini termasuk penelitian dengan pendekatan kuantitatif. Jumlah sampel 12 koperasi simpan pinjam. Sampel dipilih menggunakan metode purposive sampling. Responden dalam penelitian ini sebanyak 36 orang. Data dikumpulkan melalui penyebaran kuisioner. Teknik analisis data yang digunakan dalam penelitian ini yaitu analisis regresi linier berganda. Hasil penelitian menunjukkan bahwa (1) Good Corporate Governance (GCG) dan manajemen risiko secara simultan berpengaruh terhadap kinerja keuangan. (2) Good Corporate Governance (GCG) secara parsial berpengaruh terhadap kinerja keuangan. (3) Manajemen Risiko secara parsial berpengaruh terhadap kinerja keuangan.

Kata Kunci : Good Corporate Governance (GCG), manajemen risiko dan Kinerja keuangan.

\section{Abstract}

This study aimed at examining the effect of good corporate governance (GCG) and risk management on financial performance in cooperatives in Buleleng district. This research employed a quantitative approach. The samples of 12 savings and loans cooperatives. The sample was selected using a purposive sampling method. Respondents in this study were 36 people. The data were collected through questionnaires. The data analysis technique used in this research was multiple linear regression analysis. The results showed Good Corporate Governance (GCG) and risk management simulated affect financial performance. (2) Good Corporate Governance (GCG) partially affects financial performance. (3) Risk Management partially affects financial performance.

Keywords: Good Corporate Governance (GCG), risk management and financial performance.

\section{Pendahuluan}

Perkembangan bisnis Persaingan global dan serbuan perusahaan tradisional yang cenderung eksploitatif dan imperialisme serta perkembangan perekonomian yang sangat pesat seiring dengan perkembangan ilmu dan teknologi, menjadi salah satu pertimbangan penting dalam menentukan kebijakan perekonomian berbasis masyarakat untuk mewujudkan masyarakat adil dan makmur sebagaimana tercantum dalam Pembukaan Undang - Undang Dasar 1945. Untuk menegakkan dan memperjuangkan ekonomi kerakyatan, lembaga koperasi diyakini merupakan wadah yang paling tepat dan sesuai dengan kepribadian bangsa Indonesia. Masyarakat sudah mulai menyadari manfaat dibentuknya koperasi bagi kehidupan. Jika dilihat koperasi sebagai unit usaha, pengelolaan koperasi harus juga mempunyai kinerja yang baik sebagai pertanggung jawaban kepada seluruh anggotanya yang berkedudukan sebagai pemilik koperasi.




Pengelolaan manajemen koperasi didasarkan pada aturan yang berlaku diantaranya Anggaran Dasar (AD) / Anggaran Rumah Tangga (ART), kebijakan, struktur organisasi, peran dan aturan yang memiliki fungsinya masingmasing sesuai dengan jobdesk dari para pengurus, pengawas dan pengelola dilakukan secara tersistem dalam menjalankan koperasi yang berlandaskan visi dan misi serta tata kelola Good Corporate Governance (GCG) koperasi yang transparan, mandiri, memiliki akuntabilitas, pertanggungjawaban dan kewajaran. Serta kurangnya perhatian sisstem informasi dalam pengembangan diri koperasi untuk mempermudah informasi dan mempermudah pengelolaan koperasi sehingga pengambilan keputusan lebih cepat.

Koperasi sebagai sebuah lembaga keuangan bersifat kekeluargaan dan sudah melekat dihati masyarakat Indonesia sudah seharusnya menjadi fokus pemerintah untuk kembali menjadikan koperasi sebagai sebuah lembaga keuangan yang dipercaya oleh masyarakat Indonesia. Koperasi harus mampu meningkatkan kinerjanya melalui penerapan prinsipprinsip GCG. Walaupun prinsip dasar dari koperasi adalah sukarela akan tetapi koperasi juga harus dikelola oleh tenaga-tenaga profesional, karena maksud dari sukarela disini adalah bagaimana anggota, pengelola, pengurus dan badan pengawas sama-sama ingin membangun koperasi dan dapat merasakan manfaat dari koperasi itu sendiri. Sehingga koperasi yang terkelola sesuai dengan prinsip tata kelola perusahaan yang baik mampu menumbuhkan perekonomian masyarakat Indonesia.

Lemahnya penerapan tata kelola didalam perusahaan menjadi pemicu terjadinya skandal pada bisnis perusahaan, dan menyadarkan orang akan perlunya sistem tata kelola yang baik. Mulai saat itu banyak pihak yang berpikir bahwa penerapan corporate governance menjadi sebuah kebutuhan di dalam dunia bisnis yang digunakan sebagai barometer akuntabilitas dari sebuah organisasi bisnis (Dewayanto, 2010). Good governance harus selalu menyesuaikan dengan keadaan, perkembangan, serta sistem hukum suatu negara, sehingga praktik Good Governance tiap Negara berbeda (Wibowo, 2010). Tingkat pertumbuhan ekonomi suatu Negara mampu menjadi tolok ukur kemajuan dari Negara itu sendiri (Krismaya Dewi dan Putri, 2014). Negara yang mempunyai tingkat pertumbuhan ekonomi yang baik cenderung karena lembaga keuangannya yang juga baik. Sumber pendanaan masyarakat Indonesia berasal dari lembaga keuangan bank dan non bank. Terdapat beberapa lembaga keuangan yang dapat digunakan khususnya masyarakat di Bali, seperti Bank Umum, Bank Perkreditan Rakyat, Lembaga Perkreditan Desa, dan Koperasi.

Koperasi simpan pinjam di Kecamatan Buleleng terdapat 31 koperasi yang tersebar dibeberapa tempat wilayah kecamatan buleleng, di antaranya 20 koperasi yang termasuk kategori masih aktif dan 11 koperasi yang sudah non aktif. Koperasi Simpan Pinjam (KSP) yang non aktif adalah KSP Sari Kumala, KSP Pagosadata, KSP Darma Yasa Sri Rejeki, KSP Sari Amerta Sari, KSP Sami Liang, KSP Karya Buleleng Bersatu, KSP Ayu Luwih, KSP Mandiri, KSP Bina Insani, KSP Suryanadi, dan KSP Dana Samudra. Kondisi 11 koperasi simpan pinjam yang mengalami non aktif menunjukkan bahwa terdapat permasalahan dalam pengelolaan keuangan koperasi simpan pinjam. Koperasi yang tidak aktif karena tidak adanya tata kelola yang baik (www.balipost.com).

Keberhasilan dapat dicapai apabila koperasi sudah memiliki pedoman yang baik dalam mengelola sumber daya yang ada. Good Corporate Governance atau tata kelola perusahaan yang baik merupakan pedoman yang sangat efektif digunakan oleh koperasi untuk meningkatkan daya saing serta akan menciptakan pedoman bagi pengelola koperasi dengan mengelola manajemennya yang baik dengan memperhatikan kepentingan stakholders (stakeholders di lingkungan koperasi). Penerapan good corporate governance diharapkan dapat meningkatkan kinerja serta nilai dari koperasi sendiri dengan memperoleh dana pembiayaan yang lebih murah (Hindistari dan Putri, 2016). Menurut Komite Nasional 
Kebijakan Governance atau KNKG (2006:5) prinsip-prinsip good corporate governance antara lain : transparancy (keterbukaan), accountability (akuntabilitas), responsbility (responsibilitas), indepedency (kemandirian), dan fairness (kewajaran dan kesetaraan). Prinsip GCG dibutuhkan agar tercapainya kesinambungan usaha (sustainability) perusahaan dengan memperhatikan stakeholder (KNKG, 2006:5).

Lembaga keuangan sebagian besar sangat memegang peranan penting dalam mendukung perkembangan perekonomian yang ada di Indonesia. Perusahaan akan menghadapi risiko dan tantangan yang semakin sering akan terjadi. Risiko dan tantangan ini dapat terjadi dikarenakan perusahaan ingin mencapai tujuan yang telah ditetapkan, salah satunya mencapai laba maksimal (Ariestya dan Ardhana, 2016). Manajemen risiko merupakan salah satu upaya dalam praktek berkoperasi untuk memperkecil ruang dan kesempatan para pembobol koperasi. Risiko kredit, risiko likuiditas, dan risiko operasional merupakan beberapa risiko yang sering dihadapi institusi perbankan (Darmawi, 2011:16). Koperasi dalam menjalankan operasinya tentu tidak lepas dari berbagai macam risiko. Salah satu risiko yang sering dihadapi koperasi adalah risiko operasional. Risiko operasional merupakan risiko yang disebabkan oleh kurang berfungsinya proses internal bank, humam eror, kegagalan sistem teknologi, atau akibat permasalahan eksternal (Majid, 2015). Indikator yang digunakan untuk mengukur risiko operasional adalah menggunakan rasio Beban Operasioanal terhadap Pendapatan Operasional (BOPO). Rasio BOPO digunakan untuk mengukur kemampuan manajemen bank dalam mengendalikan biaya operasional terhadap pendapatan operasional (Nurintan, 2016). BOPO yang tinggi menunjukan tingkat efisiensi yang rendah dari bank dalam menjalankan usahanya sehingga menyebabkan kerugian (Majid, 2015).

Good corporate governance dan kinerja keuangan perusahaan memiliki hubungan yang kuat (Yahya dan Shukeri, 2014). Penerapan sistem Good corporate governance yang baik dapat berpengaruh pada profitabilitas perusahaan (Bistrova dan Lace, 2012). Nilai perusahaan sangat dipengaruhi oleh variabel good corporate governance yang dilakukan dan variabel ini juga berpengaruh terhadap kinerja keuangan (Setyawan dan Putri, 2013). Ukuran profitabilitas pada industri perbankan yang digunakan pada umumnya adalah Return On Asset (ROA) dan Return On Equity (ROE). Penelitian ini menggunakan ukuran ROA sebagai ukuran kinerja keuangan koperasi. Karena ROA berfokus terhadap kemampuan perusahaan untuk memperoleh earning dalam operasinya (Sudiyatno dan Suroso, 2010).

Berdasarkan uraian di atas, koperasi merupakan komponen penting bagi perekonomian di Indonesia. Koperasi merupakan bagian dari sistem pasar yang akan bersaing dalam memberikan pelayanan masyarakat. Oleh karena itu untuk menciptakan keunggulan dalam bersaing di dunia perekonomian, koperasi harus menerapkan tata kelola yang baik. Penerapan manajemen risiko dalam koperasi akan mampu membuat bisnis koperasi menjadi sehat dan meminimalisir terjadinya kebangkrutan dalam bisnis koperasi. Oleh karena itu peneliti ingin meneiliti "Pengaruh Implementasi Good Corporate Governance Dan Manajemen Risiko Pada Kinerja Keuangan Koperasi Simpan Pinjam Di Kecamatan Buleleng". Penelitian ini menggunakan data tahun 2017 - 2019.

Berdasarkan latar belakang dan rumusan masalah, adapun tujuan penelitian ini adalah untuk mengetahui hal-hal sebagai berikut: (1) Pengaruh prinsip-prinsip good corporate governance dan manajemen risiko secara simultan pada kinerja keuangan koperasi simpan pinjam di Kecamatan Buleleng. (2) Pengaruh prinsip-prinsip good corporate governance (transparancy, accountability, responsibility, independency, dan fairness) pada kinerja keuangan koperasi simpan pinjam di Kecamatan Buleleng. (3) Pengaruh manajemen risiko pada kinerja keuangan koperasi simpan pinjam di Kecamatan Buleleng. 
Pengaruh prinsip-prinsip good corporate governance dan manajemen risiko secara simultan pada kinerja keuangan

Hubungan antara good corporate governance dan manajemen risiko terhadap kinerja keuangan dikemukakan oleh Indra Siswanti (2016) menyatakan bahwa penerapan good corporate governance yang baik akan memperkecil atau meminimalkan risiko-risiko yang ada dalam perbankan sehingga apabila kedua variabel ini diterapkan secara bersama-sama serta memperoleh predikat baik maka akan mempengaruhi kondisi kinerja keuangan suatu perbankan. Pernyataan tersebut didukung juga oleh penelitian yang dilakukan Sari Indah (2020) yang menyatakan self assessment good corporate governance pada perbankan maka akan meningkatkan kinerja keuangannya, begitu juga ketika manajemen risiko perbankan diterapkan dengan baik maka akan memperkecil terjadinya risiko perbankan sehingga dapat meningkatkan kinerja keuangannya.

$\mathrm{H}_{1}$ : Ada pengaruh secara simultan prinsip-prinsip good corporate governance dan manajemen risiko pada kinerja keuangan koperasi simpan pinjam di Kecamatan Buleleng

Pengaruh prinsip prinsip good corporate governance (transparancy, accountability, responsibility, independency, dan fairness) pada kinerja keuangan

Good Corporate Governance (GCG) merupakan suatu sistem (input, proses, output) dan seperangkat peraturan yang mengatur hubungan antara berbagai pihak yang kepentingan (stakeholders) terutama dalam arti sempit hubungan antara pemegang saham, dewan komisaris, dan dewan direksi demi tercapainya tujuan perusahaan (Wahyudin, 2008). Menurut hasil penelitian Suci (2013) dalam penelitian Pradnyaswari (2016) responsibility secara parsial berpengaruh terhadap kinerja perusahaan. Indepedency adalah suatu keadaan dimana perusahaan dikelola secara profesional tanpa benturan kepentingan dan pengaruh atau tekanan dari pihak manapun yang tidak sesuai dengan peraturan perundang-undangan yang berlaku dan prinsip-prinsip korporasi yang sehat (Suci, 2013). Prinsip ini mensyaratkan agar perusahaan dikelola tanpa adanya benturan dan intervensi dari pihak manapun yang tidak sesuai dengan peraturan - peraturan yang berlaku. Fairness menuntut adanya perlakuan yang adil dalam memenuhi hak stakeholder sesuai dengan perundangan yang berlaku. Menurut penelitian Rahmatika dkk.(2015) menyatakan pengaruh antara kewajaran terhadap kinerja keuangan menunjukan koefisien positif, hal ini menunjukkan bahwa kewajaran berpengaruh signifikan terhadap kinerja keuangan. Dengan demikian hasil penelitian ini menunjukkan bahwa kewajaran berpengaruh terhadap kinerja keuangan. Hal tersebut sejalan dengan peneliti Krismaya Dewi dan Putri (2014) yang menyatakan prinsip - prinsip good corporate governance berpengaruh terhadap kinerja keuangan LPD di Kabupaten Gianyar Bali. Serta didukung oleh penelitian Ridwan (2008) yang menyatakan bahwa prinsip GCG berpengaruh terhadap kinerja keuangan.

$\mathrm{H}_{2}$ : Ada pengaruh secara parsial good corporate governance pada kinerja keuangan koperasi simpan pinjam di Kecamatan Buleleng

\section{Pengaruh manajemen risiko pada kinerja keuangan}

Berdasarkan Surat Edaran Bank Indonesia (SEBI) No.6/23/2004, nilai maksimal Beban Operasional terhadap Pendapatan Operasional (BOPO) adalah sebesar 94\%. Jika suatu bank memiliki nilai BOPO lebih dari ketentuan yang telah ditentukan maka bank tersebut masuk dalam kategori tidak efisien, karena semakin tinggi BOPO berarti peningkatan biaya operasionalnya semakin besar daripada peningkatan pendapatan operasionalnya sehingga laba yang diperoleh turun dan ROA menurun. Menurut Nuritan (2016) dalam wirawan (2018) menyatakan bahwa risiko operasional dapat digunakan untuk mengetahui kesehatan 
dari koperasi itu sendiri. Biaya operasional digunakan untuk mengukur tingkat efisiensi dan kemampuan bank dalam melakukan kegiatan operasionalnya. Semakin kecil BOPO menunjukkan semakin efisien bank dalam menjalankan aktivitas usahanya sehingga semakin baik bank tersebut begitu juga dengan koperasi. Dengan kata lain, rasio BOPO berpengaruh terhadap ROA. Hal itu tidak sejalan dengan penelitian Wirawan (2018) yang menyatakan manajemen risiko berpengaruh negatif pada kinerja keuangan.

$\mathrm{H}_{3}$ : Ada pengaruh secara parsial manajemen risiko pada kinerja keuangan koperasi simpan pinjam di Kecamatan Buleleng

\section{Metode}

Penelitian ini dilakukan untuk memperoleh gambaran tentang pengaruh prinsipprinsip good corporate governance dan manajemen risiko pada kinerja keuangan koperasi simpan pinjam di Kecamatan Buleleng. Jenis penelitian yang digunakan adalah penelitian kuantitatif. Menurut Sugiyono (2016), penelitian kuantitatif adalah metode penelitian yang berlandaskan filsafal positivisme, digunakan untuk meneliti pada populasi atau sampel tertentu, pengumpulan data menggunakan instrumen penelitian, analisis data bersifat kuantitatif/statistk dengan tujuan untuk menguji hipotesis yang telah ditetapkan.

Variabel dalam penelitian ini dibagi menjadi dua yaitu variabel bebas dan variabel terikat. Variabel bebas dalam penelitian ini adalah good corporate governance (x1) dan manajemen risiko (x2), sedangkan variabel terikat dalam penelitian ini adalah kinerja keuangan (Y). Untuk membantu proses pengolahan data secara tepat dan cepat, maka pengolahan data dilakukan dengan menggunakan bantuan dengan program computer Statistical Package for Social Science (SPSS) 20 for windows.

Penelitian ini dilakukan pada koperasi simpan pinjam di kecamatan buleleng yang berbadan hukum dan memberikan laporan keuangan dari tahun 2017-2019 dan jenis data yang digunakan adalah data kuantitatif berupa data primer melalui kuisioner dan data sekunder yang diperoleh dari laporan keuangan 12 koperasi simpan pinjam yang tersebar di Kecamatan Buleleng.

Teknik analisis data yang digunakan adalah analisis regresi linier berganda. Data yang akan dianalisis dalam penelitian ini berkaitan dengan hubungan antar variabel- variabel. Analisis data dilakukan secara kuantitatif dengan tahapan yaitu: (1) uji asumsi klasik, (2) analisis regresi linier berganda dan (3) koefisien determinasi. Tujuannya adalah menetapkan apakah variabel bebas mempunyai hubungan dengan variabel terikatnya, penetapan tingkat signifikansi, dan diakhiri dengan penelitian dasar penarikan kesimpulan melalui penerimaan atau penolakan hipotesis.

\section{Hasil dan Pembahasan}

\section{Analisis Regresi Linear Berganda}

Adapun hasil pengujian hipotesis dengan menggunakan analisis regresi linier berganda pada struktur pengaruh good corporate governance dan manajemen risiko pada kinerja keuangan koperasi simpan pinjam di kecamatan Buleleng dapat dilihat pada gambar 1 . 


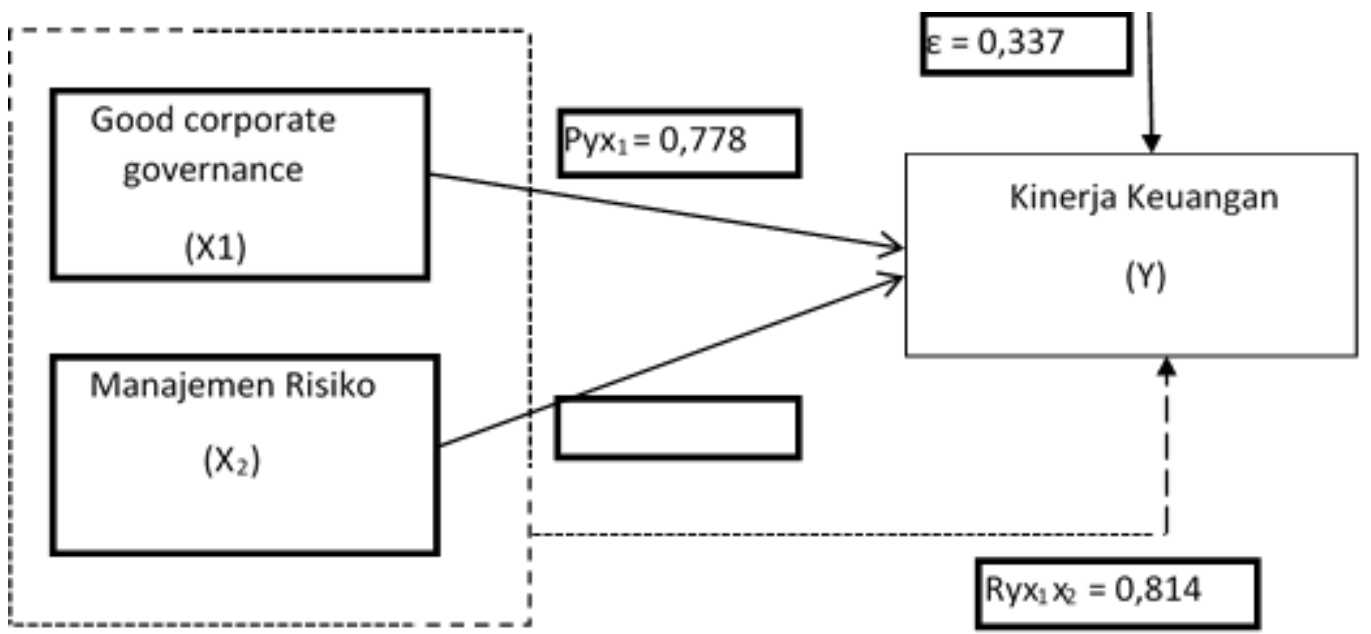

Gambar 1. Struktur Pengaruh Good Corporate Governance (X1), Manajemen Risiko (X2 ) pada Kinerja Keuangan (Y).

Hipotesis penelitian pertama "Ada pengaruh simultan dari good corporate governance dan manajemen risiko pada kinerja keuangan" berdasarkan rekapan hasil uji regresi berganda menunjukan hasil Ryx $1 \times 2=0,814$ dengan $\mathrm{p}$-value $0,000<$ alpha 0,05 dengan demikian keputusan yang diambil adalah Ho ditolak dan Ha diterima. Hasil ini berarti secara simultan ada pengaruh good corporate governance dan manajemen risiko pada kinerja keuangan pada kinerja keuangan koperasi simpan pinjam di Kecamatan Buleleng. Besarnya sumbangan pengaruh simultan dari good corporate governance dan manajemen risiko terhadap kinerja keuangan sebesar 0,663 (66,3\%). Hasil tersebut menunjukkan bahwa sebesar $66,3 \%$ kinerja keuangan dipengaruhi oleh good corporate governance dan manajemen risiko, sementara itu sebesar 0,337 (33,7\%) dipengaruhi oleh variabel lain.

Hipotesis penelitian kedua "Ada pengaruh dari good corporate governance terhadap kinerja keuangan" berdasarkan rekapan hasil uji regresi berganda diperoleh hasil yaitu besarnya pengaruh struktur modal sebesar $0,778(77,8 \%)$ dengan p-value $0,000<$ alpha 0,05 yang menyatakan bahwa Ho ditolak dan Ha diterima. Hasil ini menunjukkan adanya pengaruh positif dan signifikan good corporate governance terhadap kinerja keuangan koperasi simpan pinjam di Kecamatan Buleleng. Besar sumbangan pengaruh pengaruh good corporate governance terhadap kinerja keuangan sebesar $60,52 \%$.

Hipotesis penelitian ketiga "Ada pengaruh dari manajemen risiko terhadap kinerja Keuangan" berdasarkan rekapan hasil uji regresi berganda diperoleh hasil yaitu besarnya pengaruh manajemen risiko sebesar $0,518(51,8 \%)$ dengan p-value $0,001<$ alpha 0,05 menyatakan bahwa Ho ditolak dan Ha diterima. Hasil ini menunjukkan adanya pengaruh positif dan signifikan manajemen risiko terhadap kinerja keuangan koperasi simpan pinjam di Kecamatan Buleleng. Besar sumbangan pengaruh ukuran perusahaan terhadap nilai perusahaan sebesar $26,83 \%$.

Hasil penelitian ini menunjukkan bahwa secara simultan good corporate governance dan manajemen risiko pada kinerja keuangan pada kinerja keuangan koperasi simpan pinjam di Kecamatan Buleleng. Hasil ini menunjukkan bahwa semakin baik penerapan prinsipprinsip good corporate governance dan manajemen risiko maka kinerja keuangan yang dicapai akan semakin tinggi. Menurut Indra Siswanti (2016) menyatakan bahwa penerapan good corporate governance yang baik akan memperkecil atau meminimalkan risikorisiko yang ada dalam perbankan sehingga apabila kedua variabel ini diterapkan secara bersama-sama serta memperoleh predikat baik maka akan mempengaruhi kondisi kinerja keuangan suatu perbankan. Pernyataan tersebut didukung juga oleh penelitian yang dilakukan 
Sari Indah (2020) yang menyatakan self assessment good corporate governance pada perbankan maka akan meningkatkan kinerja keuangannya, begitu juga ketika manajemen risiko perbankan diterapkan dengan baik maka akan memperkecil terjadinya risiko perbankan sehingga dapat meningkatkan kinerja keuangannya.

Hasil penelitian yang telah dilakukan menunjukkan bahwa ada pengaruh positif dan signifikan good corporate governance pada kinerja keuangan pada kinerja keuangan koperasi simpan pinjam di Kecamatan Buleleng. Good Corporate Governance (GCG) merupakan suatu sistem (input, proses, output) dan seperangkat peraturan yang mengatur hubungan antara berbagai pihak yang kepentingan (stakeholders) terutama dalam arti sempit hubungan antara pemegang saham, dewan komisaris, dan dewan direksi demi tercapainya tujuan perusahaan (Wahyudin, 2008). Menurut hasil penelitian Suci (2013) dalam penelitian Pradnyaswari (2016) responsibility secara parsial berpengaruh terhadap kinerja perusahaan. Indepedency adalah suatu keadaan dimana perusahaan dikelola secara profesional tanpa benturan kepentingan dan pengaruh atau tekanan dari pihak manapun yang tidak sesuai dengan peraturan perundang-undangan yang berlaku dan prinsip-prinsip korporasi yang sehat (Suci, 2013). Prinsip ini mensyaratkan agar perusahaan dikelola tanpa adanya benturan dan intervensi dari pihak manapun yang tidak sesuai dengan peraturan - peraturan yang berlaku. Fairness menuntut adanya perlakuan yang adil dalam memenuhi hak stakeholder sesuai dengan perundangan yang berlaku. Menurut penelitian Rahmatika dkk.(2015) menyatakan pengaruh antara kewajaran terhadap kinerja keuangan menunjukan koefisien positif, hal ini menunjukkan bahwa kewajaran berpengaruh signifikan terhadap kinerja keuangan. Dengan demikian hasil penelitian ini menunjukkan bahwa kewajaran berpengaruh terhadap kinerja keuangan. Hal tersebut sejalan dengan peneliti Krismaya Dewi dan Putri (2014) yang menyatakan prinsip - prinsip good corporate governance berpengaruh terhadap kinerja keuangan LPD di Kabupaten Gianyar Bali. Serta didukung oleh penelitian Ridwan (2008) yang menyatakan bahwa prinsip GCG berpengaruh terhadap kinerja keuangan.

Dalam penelitian ini manajemen risiko menunjukkan bahwa ada pengaruh positif dan signifikan terhadap kinerja keuangan koperasi simpan pinjam di Kecamatan Buleleng. Hasil penelitian ini sejalan dengan Surat Edaran Bank Indonesia (SEBI) No.6/23/2004, nilai maksimal Beban Operasional terhadap Pendapatan Operasional (BOPO) adalah sebesar 94\%. Jika suatu bank memiliki nilai BOPO lebih dari ketentuan yang telah ditentukan maka bank tersebut masuk dalam kategori tidak efisien, karena semakin tinggi BOPO berarti peningkatan biaya operasionalnya semakin besar daripada peningkatan pendapatan operasionalnya sehingga laba yang diperoleh turun dan ROA menurun. Menurut Nuritan (2016) dalam wirawan (2018) menyatakan bahwa risiko operasional dapat digunakan untuk mengetahui kesehatan dari koperasi itu sendiri. Biaya operasional digunakan untuk mengukur tingkat efisiensi dan kemampuan bank dalam melakukan kegiatan operasionalnya. Semakin kecil BOPO menunjukkan semakin efisien bank dalam menjalankan aktivitas usahanya sehingga semakin baik bank tersebut begitu juga dengan koperasi. Dengan kata lain, rasio BOPO berpengaruh terhadap ROA. Hal itu tidak sejalan dengan penelitian Wirawan (2018) yang menyatakan manajemen risiko berpengaruh negatif pada kinerja keuangan.

\section{Simpulan dan Saran}

Berdasarkan hasil pembahasan yang telah dilakukan pada bab sebelumnya, maka dapat ditarik beberapa kesimpulan yaitu 1) Good Corporate Governance (GCG) dan manajemen risiko secara simultan berpengaruh terhadap Kinerja keuangan dengan hasil Ryx $1 \times 2=0,814$ dengan p-value $0,000<0,05$ dengan pengaruh sebesar 66,3\%, 2) Good Corporate Governance (GCG) secara parsial berpengaruh terhadap Kinerja keuangan dengan hasil Pyx1 $=0,778$ dengan $\mathrm{p}$-value $0,000<0,05$ dengan pengaruh sebesar $60,52 \%, 3$ ) Manajemen Risiko 
secara parsial berpengaruh terhadap Kinerja keuangan dengan hasil Pyx $2=0,518$ dengan $\mathrm{p}$ value $0,001<0,05$ dengan pengaruh sebesar $26,83 \%$.

Berdasarkan hasil simpulan yang telah dikemukakan, maka saran yang dapat dianjurkan yaitu 1) Bagi koperasi simpan pinjam Se-Kecamatan Buleleng diharapkan mampu memperkuat serta meningkatkan penerapan good corporate governance (GCG) dan manajemen risiko koperasi agar tujuan perusahaan dapat berjalan sesuai dengan yang diinginkan. Serta dapat meningkatkan ROA di koperasi dan 2) Bagi penelitian selanjutnya diharapkan dapat memperluas lokasi penelitian agar hasil yang di dapat lebih akurat, karena dalam penelitian ini hanya meneliti 12 koperasi simpan pinjam sedangkan sampelnya adalah 20 koperasi simpan pinjam. Menambah metode pengumpulan data seperti wawancara langsung ke responden apabila waktu penelitian memungkinkan akan hal tersebut, untuk menghindari respon bias akibat penggunaan kuesioner. Serta menambah variabel penelitian yang tidak ada dalam penelitian ini, seperti untuk mengukur variabel manajemen risiko tidak hanya menggunakan rasio BOPO namun dapat juga risiko-risiko lain.

\section{Daftar Pustaka}

Ariestya, Putu Yutika. dan Ardiana, Putu Agus. 2016. Implementasi Good Corporate Governance pada Kinerja Perusahaan Sektor Keuangan dengan Manajemen Risiko sebagai Variabel Intervening. Jurnal Fakultas Ekonomi dan Bisnis Universitas Udayana.

Bistrova, J., and Lace, N. 2012.Corporate Governance Influence on Firms' Financial Performance in CEE Countries.In 7th International Scientific Conference Business and Management-2012, Vilnius, not published.

Brigham, Eugene F. dan Houston. 2006. Fundamental of Financial Management : DasarDasar Manajemen Keuangan. Edisi 10. Jakarta: Salemba Empat.

Budiarti, I. 2010. Penerapan Prinsip-prinsip Good Corporate Governance Pada Dunia Perbankan. JurnalManajemen, 8.

Dewayanto, T. 2010. Pengaruh Mekanisme Good Corporate Governance terhadap Kinerja Perbankan Nasional (Studi Pada Perusahaan Perbankan yang Terdaftar di Bursa Efek Indonesia Periode 2006-2008).Jurnal Fokus Ekonomi, 5(2):h:104-123.

Dietrich, Andreas and Gabrielle Wanzenried. 2009. What Determines the

Profitability of Commercial Banks? New Evidence from Switzerland.Journal.

Eisenhardt, Kathleem. M. 1989. Agency Theory: An Assesment and Review. Academy of management Review, 14, hal 57-74.

Sari, Tri Yulita. "Pengaruh Penerapan Prinsip Good Corporate Governance terhadap kinerja perusahaan BUMN Kota Palembang. Palembang :Universitas Muhamaddiah Palembang". (diunduh melalui : http://repository.umpalembang.ac.id/id/eprint/235/2/SKRIPSI139-1704107126.pdf)

Sari, Indah. "Pengaruh Self Assessment Good Corporate Governance dan Manajemen Risiko terhadap Kinerja Keuangan (Studi Kasuspada Perusahaan Perbankan yang Terdaftar di BEI Tahun 2016-2018)". (diunduh melalui:http://digilib.uinsby.ac.id/44010/2/Siti\%20Nur\%20Indah\%20Sari_G72216079.p df)

Siswanti, Indra. "Implementasi Good corporate governance Pada Kinerja Bank Syariah". 
Jurnal Akuntansi Multiparadigma, No. 2012 (2016): 307-321.

Sugiono. 2013. Metode Penelitian Kuantitatif, Kualitatif dan R\&D. Bandung: Penerbit Alfabeta..

Wahyudin Zarkasyi. 2008. Good Corporate Governance pada Perusahaan Manufaktur dan Perbankan. Bandung: Alfabeta. 